\title{
The Ebook Avant-Garde
}

Books in Browsers $\mathrm{V}$ October 24, 2014

Sanders Kleinfeld

O’Reilly Media, Inc. 
What do we mean by "avant-garde"? 
Avant-Garde!

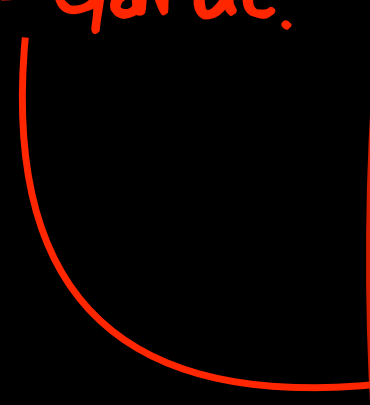

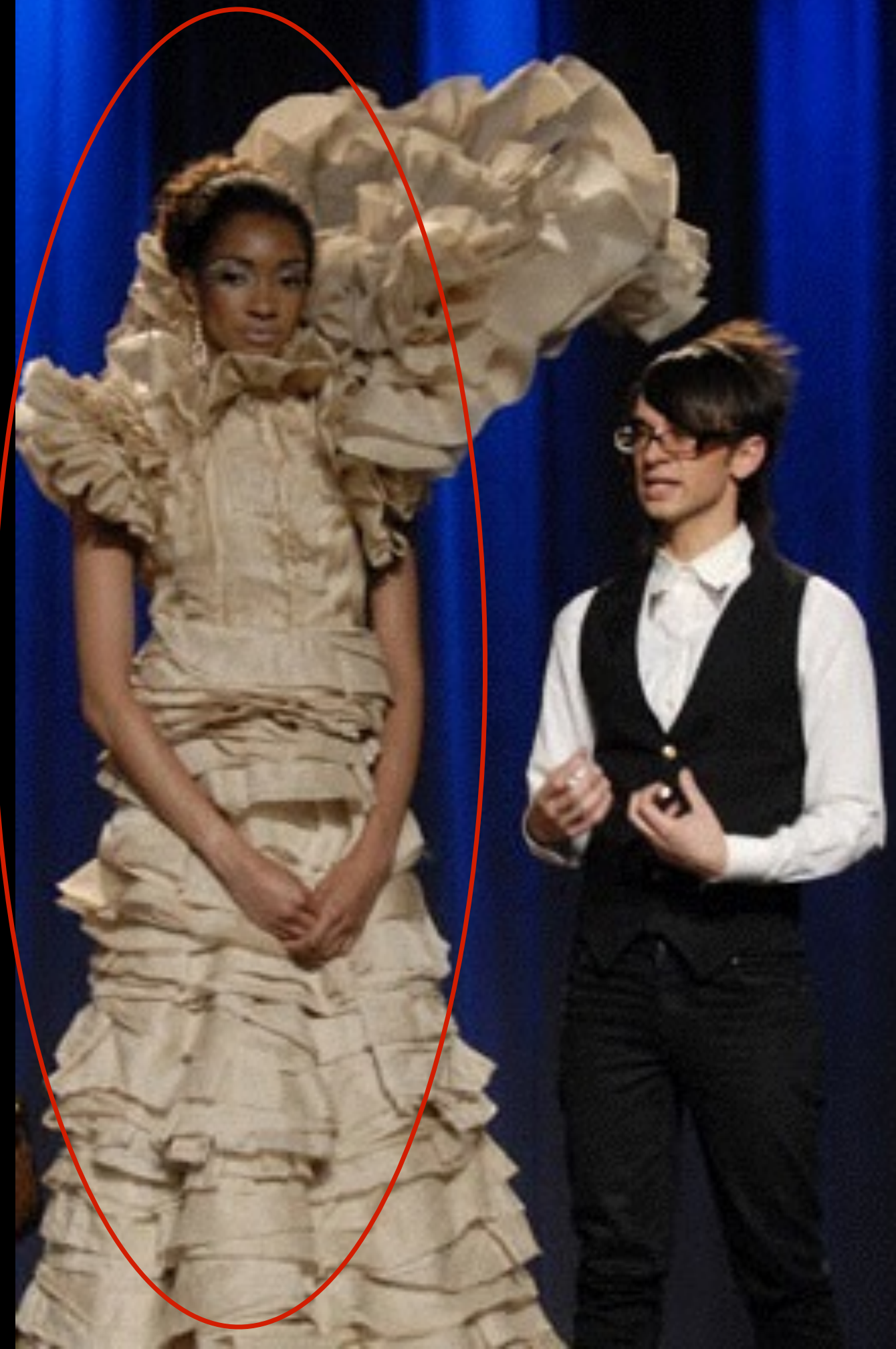

http://img2-3.timeinc.net/ew/dynamic/imgs/080226/christian-chris_ep8_1.jpg 


\section{What do we mean by "avant-garde" literature?}


$\mathrm{TH} \mathrm{E}$

L I F E

A N D

O $\quad$ P I I N I O N S

O F

\section{TRISTRAM SHANDY,}

GENTLEMAN.

Dixero fs quid farti jocofsus, boc mibi juris

Cum venia dabis.

Hor.

-..- Si quis calumnictur leviuss stle quam decet theologum, aut mordacius quam deceat Chriftianum-n-non $E_{g o}$, fed Demacritus dixit.--

ERAsmus.

V O L. VI.

L O N D O N:

Printed for T. Becket and P. A. DEHONDT, in the Strand. MDCCLXII.

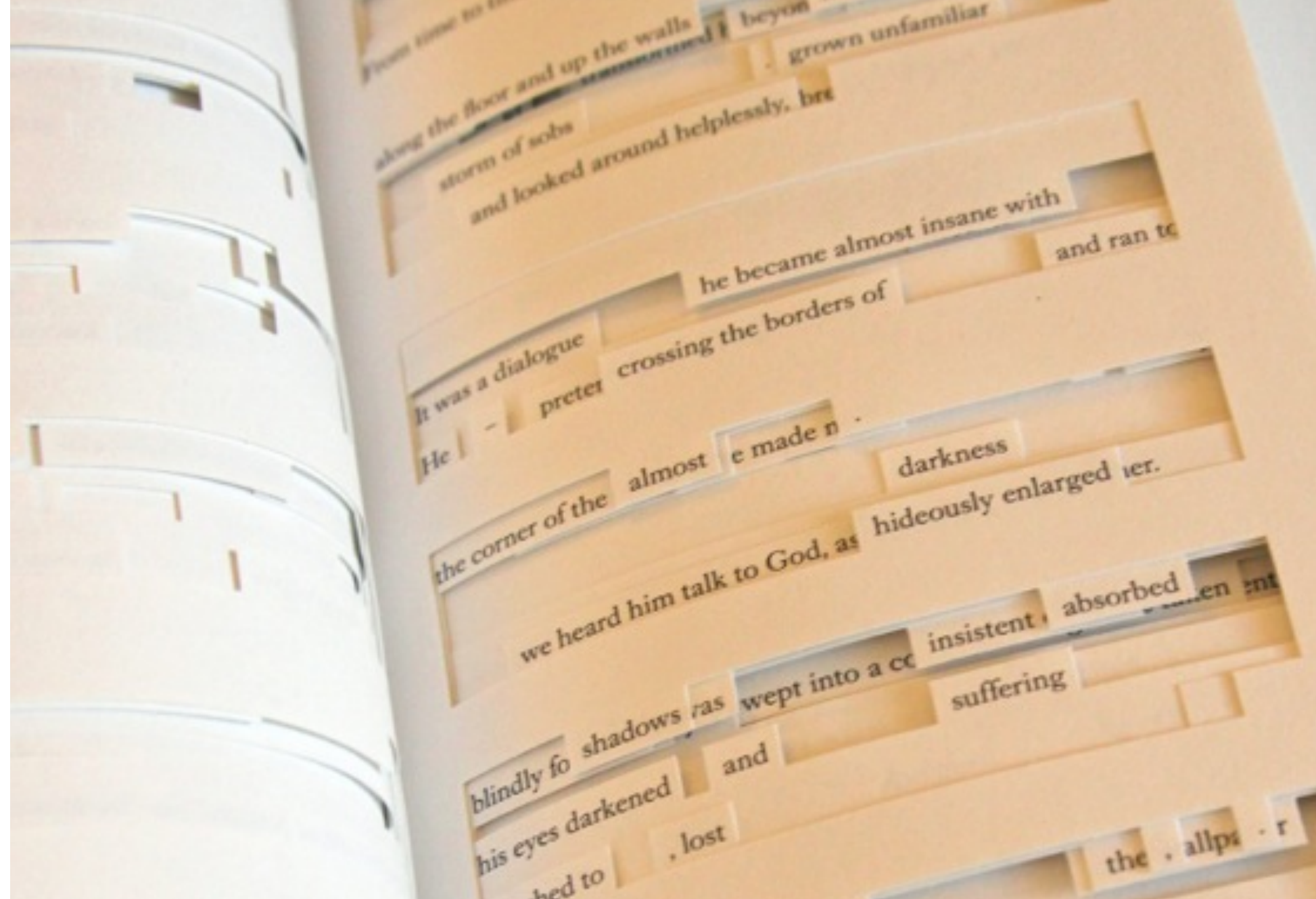

\section{JOURNEY} UNDER THE SEA
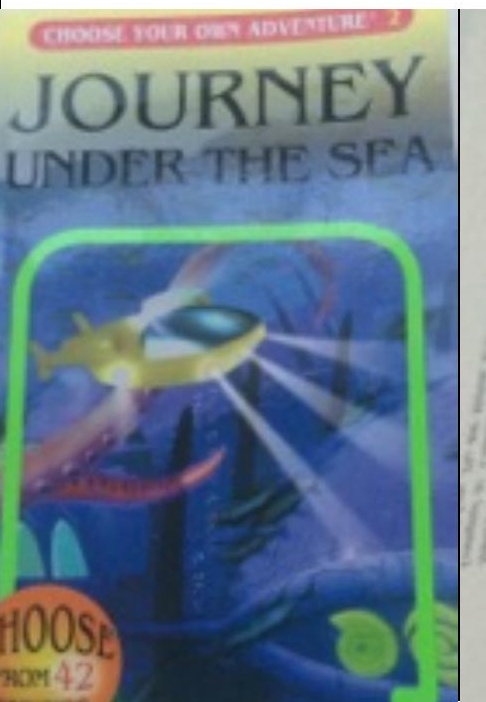

Above by mightymigh
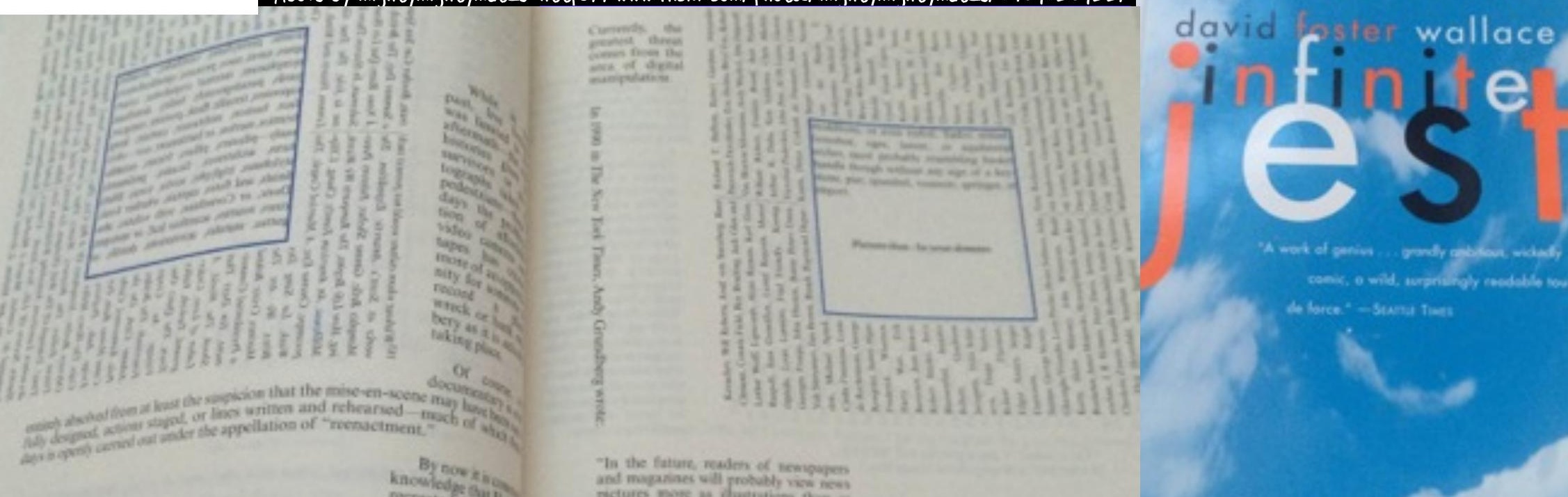

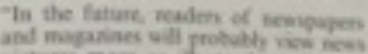


Avant-Garde != Highbrow

(although sometimes it may be) 
Avant-Garde != Good

(although sometimes it may be) 


\section{Avant-Garde ==}

Interrogation of Form 
Three principles of the ebook avant-garde 


\section{PRINCIPLE \# 1:}

"Precession" OF

BOOK SIMULACRA 
"Representation stems from the principle of the equivalence of the sign and of the real....Simulation, on the contrary, stems... from the radical negation of the sign as value...the reversion and death sentence of every reference"

—Jean Baudrillard "The Precession of Simulacra" 
Baudrillard's four "successive phases of the image," as applied to ebooks 


\section{\#1:}

\section{"it is the reflection of a profound reality"}

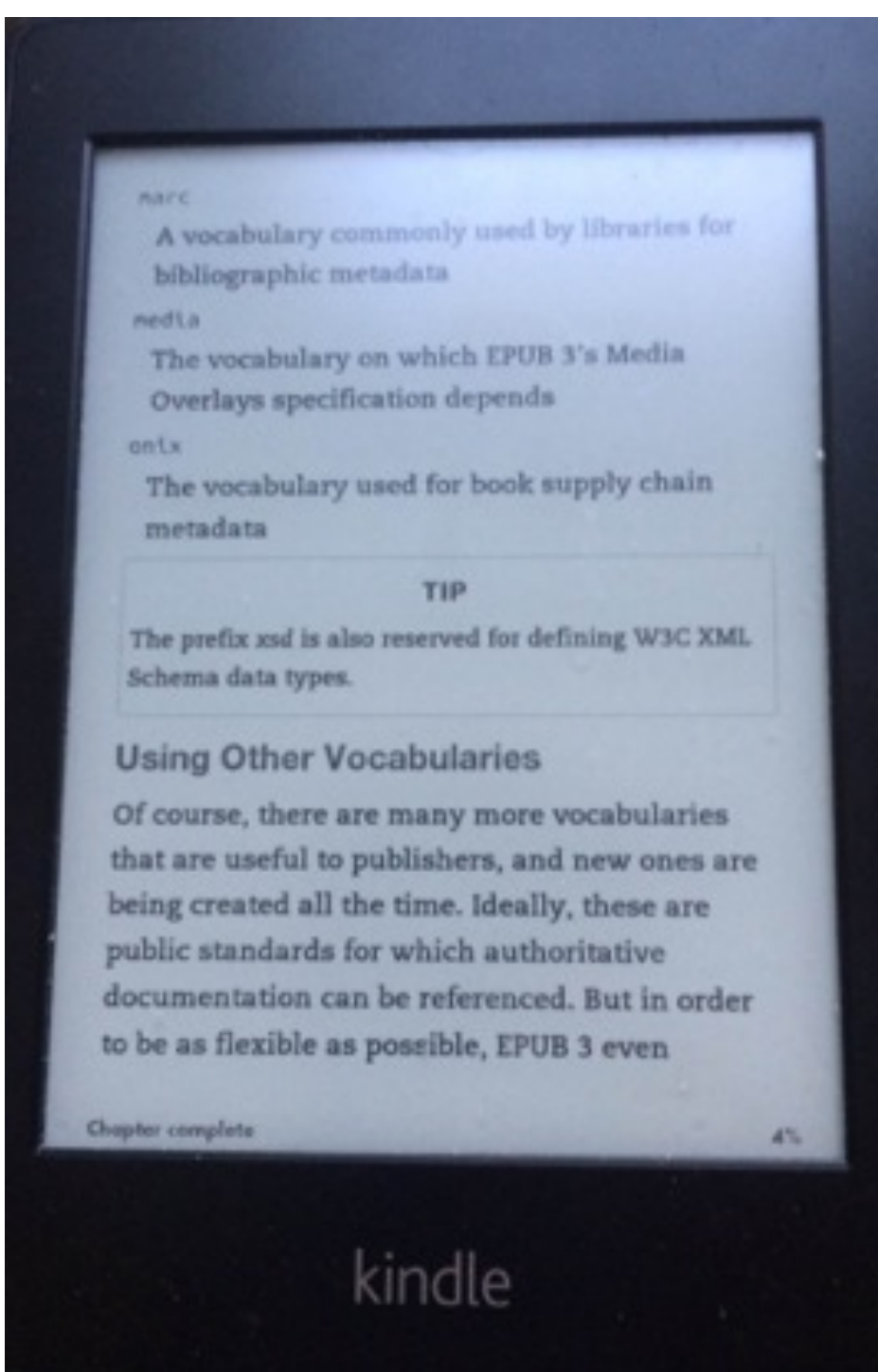




\section{\#2:}

\section{"it masks and denatures a}

profound reality"

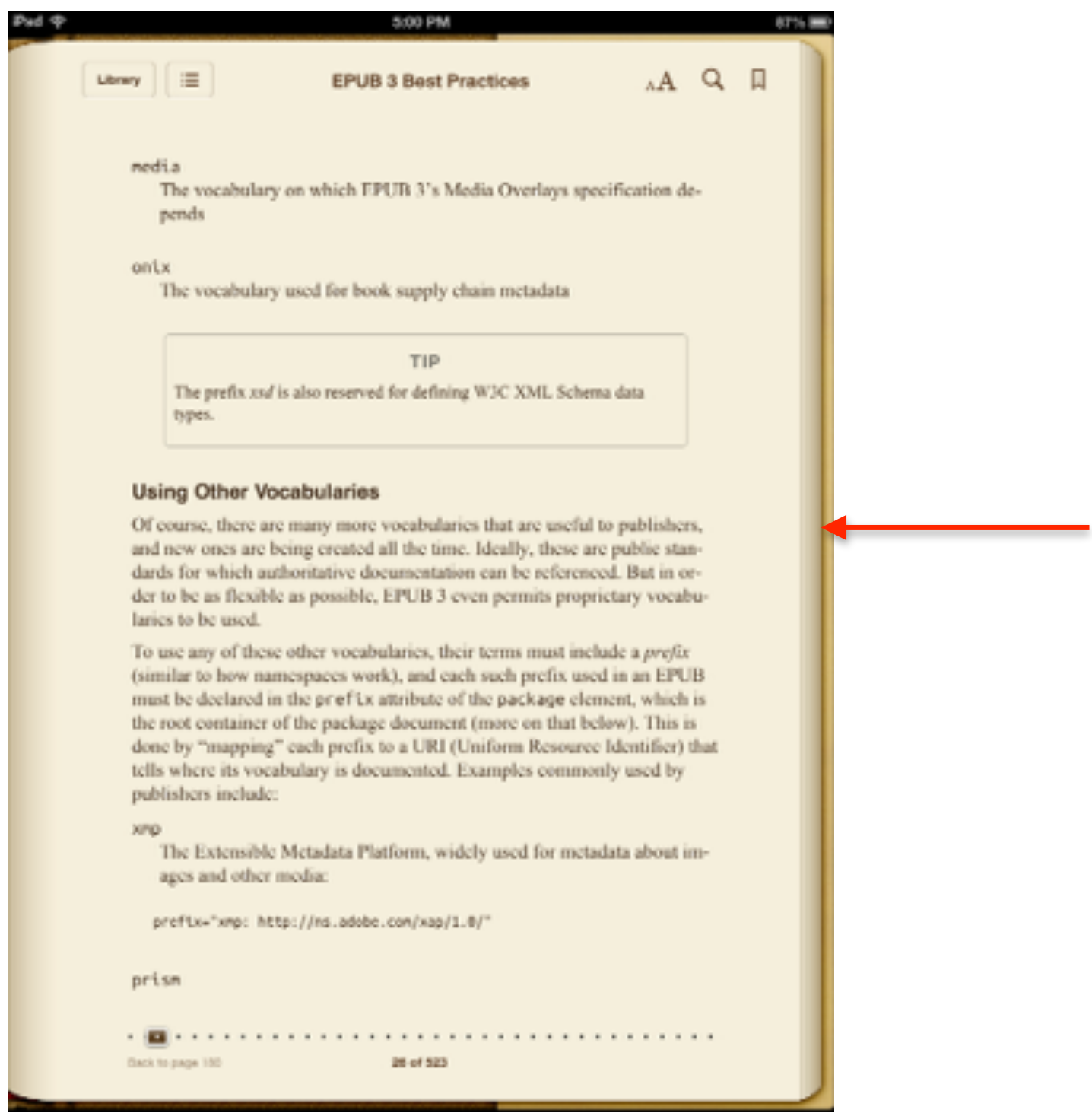


Baldur Bjarnason

Drop caps are an affectation that mocks and parodies print's long history of bespoke illustration by mutilating the first word of a chapter

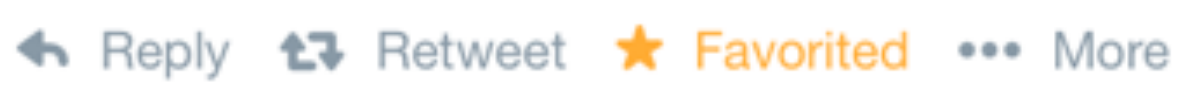

RETWEETS

FAVORITES

3 


\section{\#3:}

\section{"it masks the absence of a} profound reality"

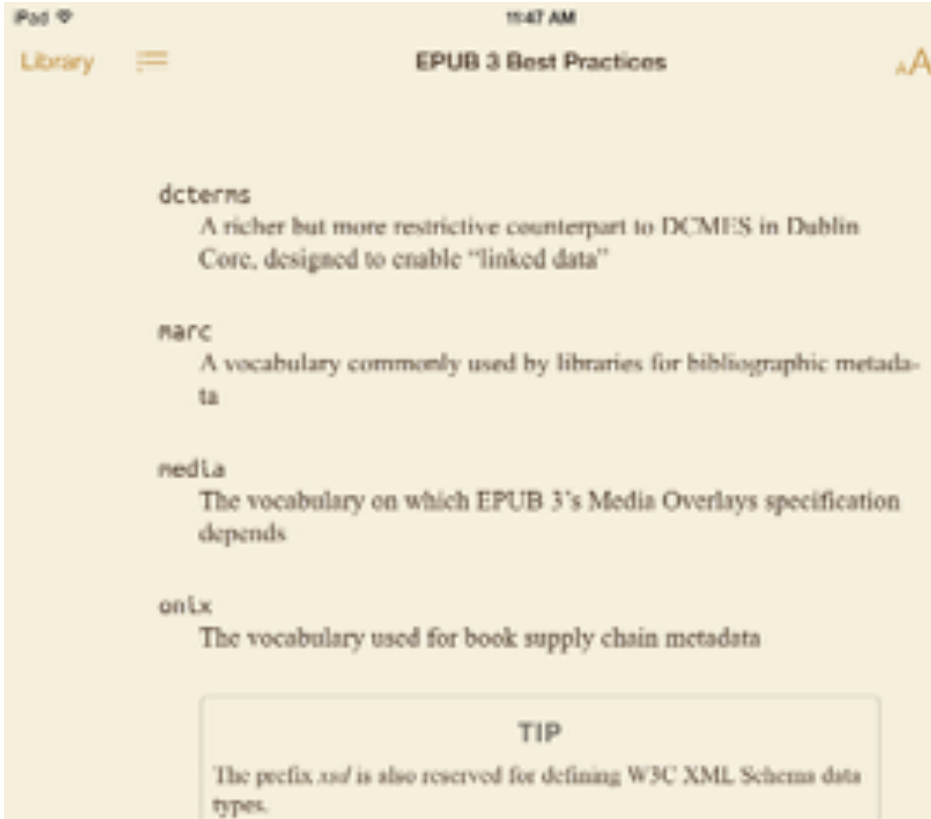

A richer but more restrictive coenterpert in DX MIS in Dablin Core. desigasd wo enable "linked data"

marc

A vecabulary commenly used by libraries for biblingraphic metada.

The vocabulary on which EPUB 3's Media Overlays specification depends

onlx

The vocabulary used for book supply chain metsdsta

TIP

The pecfis ned is alve resaved fer defining W3C XML Stheme das

\section{Using Other Vocabularies}

Of course, thete ano many more vecabularies that are useful to publishCrs, and new enes are being created all the time, lidcally, these ane pub. tic standards for which authoriative documentation ena be referenced. But in order to be as flesible as possible, EFUB 3 even peranits propri. etary rocabolaries to be used.

To use any of these other vocabularies, their lerms mest isclude a pnefic (similar to bow namespaces woek), and each such prefix used in an FPUB mast be daclared in the pref $1 \times$ atinbute of the package elemeat, which is the root container of the package document (more on that belon). This is doen by "mapping" cach prefix to a URI (Unifoem 


\section{THE
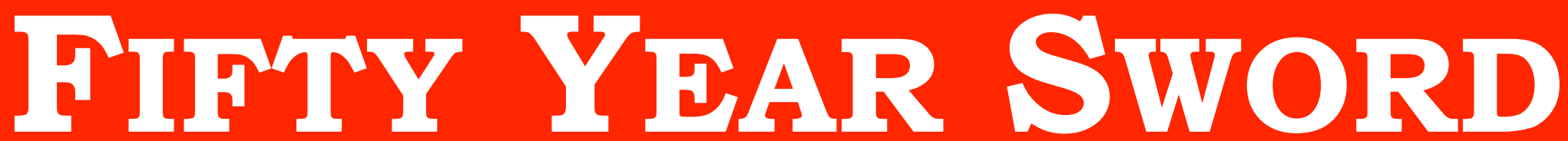

(https://itunes.apple.com/us/book/the-fifty-year-sword/id562071307? mt=11)

ease

"in those detirating ribs of her East Texas remove slunk down amidst the hickony

"and Mexican wild

\section{"plum?}

" $A$ few times a year Mose would generously serve up boose

"and sweet

"to fortipify the many strangers against

the expected strangeness of her minglings,

where someone like Chintana, a seamstress,

could find herself

"deflecting the

advances of an incbriated City Alderman.

"Mose though rarely appeared

herset. In fact running into her at all,

certainly tonight, would be like crossing

up with a ghost.

"Though a ghost would be niee.

"Crossing up with a ghost, thought Chintana, was about the only thing that would keep her from cutting her own appearance short.

S6 In fact Chintana had only gotten as far as the coat rack when she thought for the third "and last time

about retreating
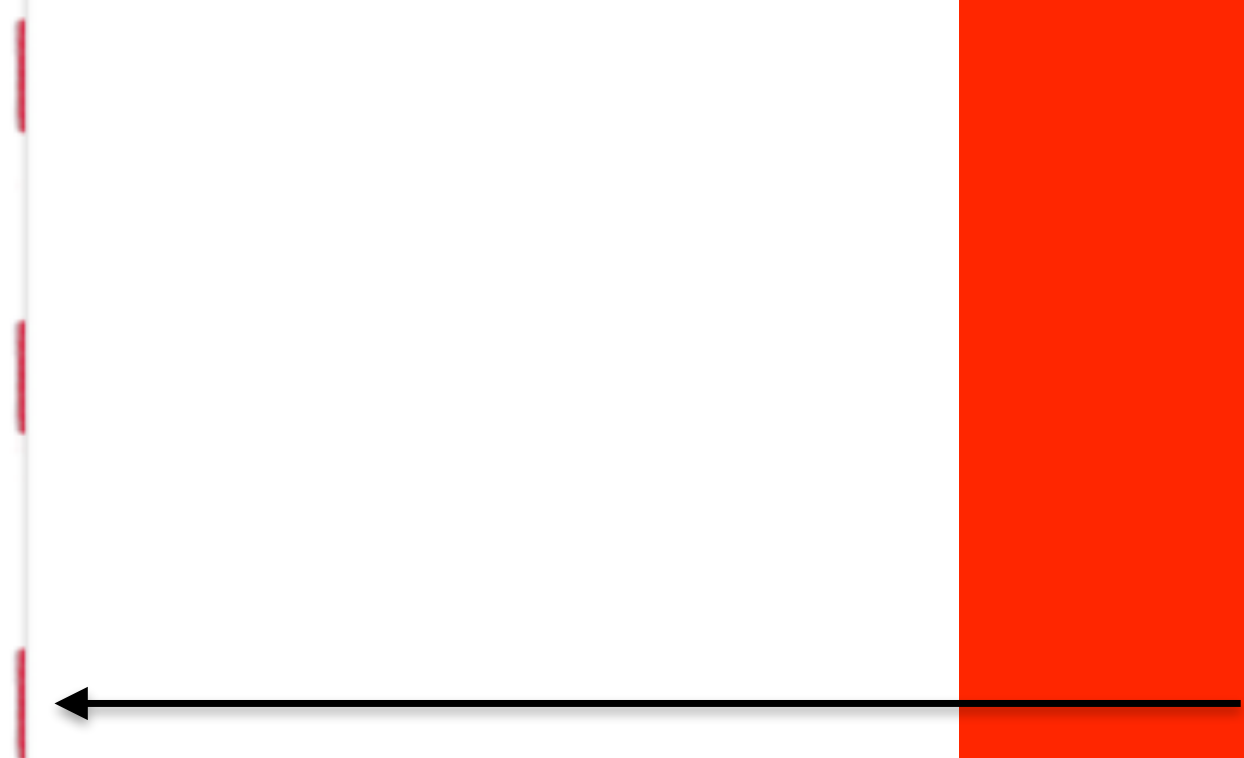


$$
\text { \#4: }
$$

"it has no relation to any reality whatsoever; it is its own pure simulacrum"

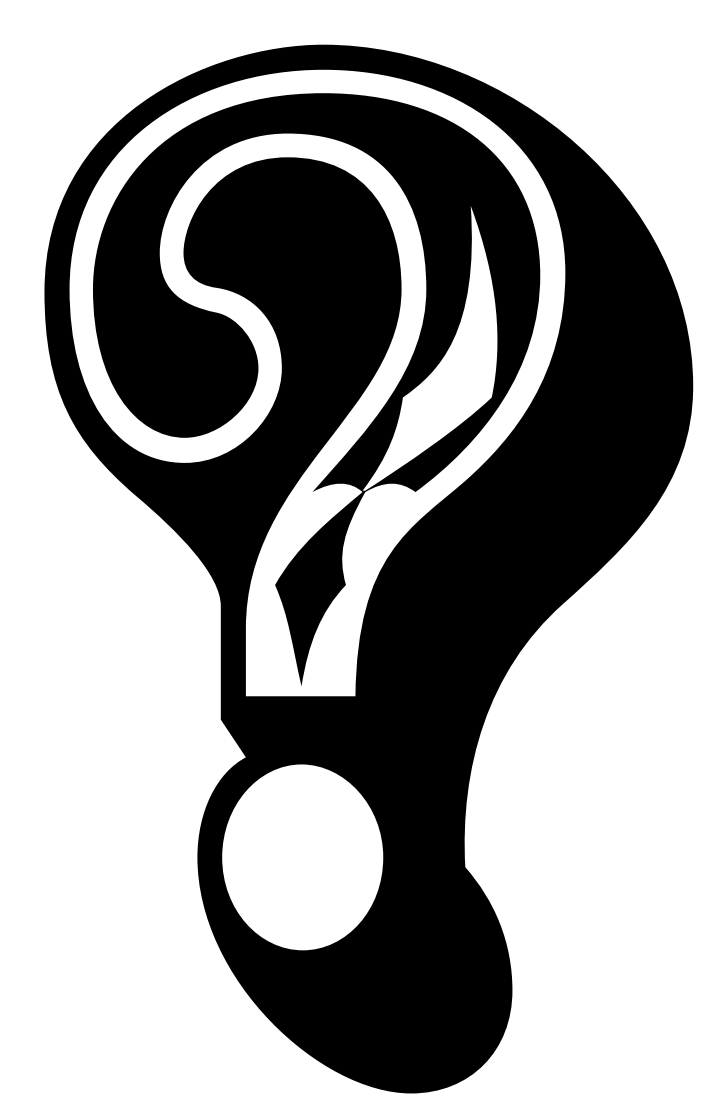




\section{DEVICE 6}

(https://itunes.apple.com/us/app/device-b/id680366065? mt=8)

WEST CORRIDOR

Across the hall Anna noticed a stairway that led down to what she a

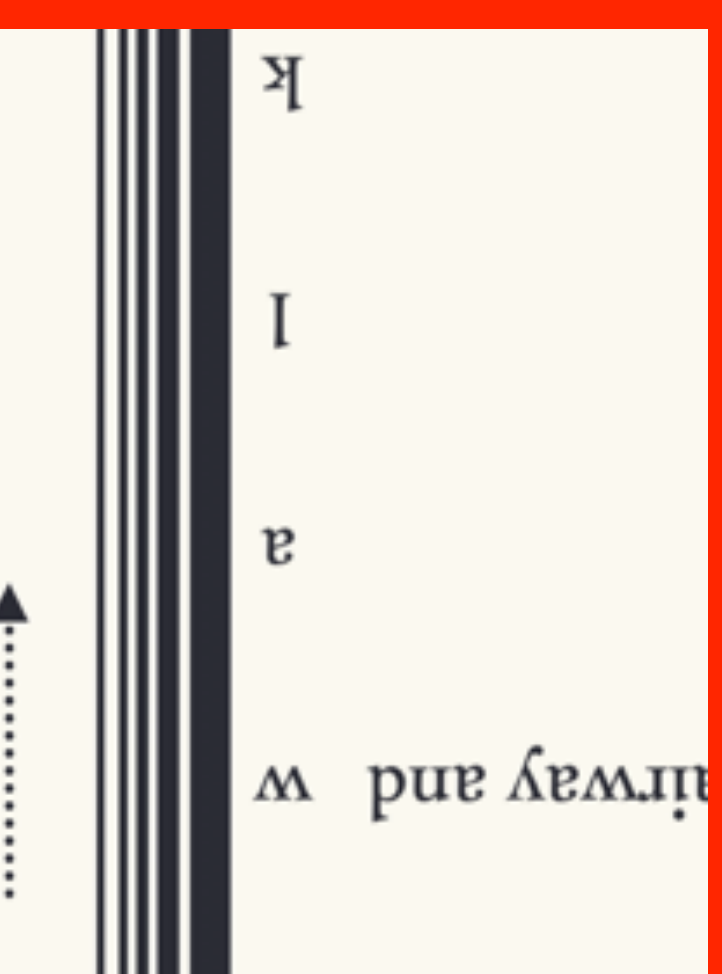




\section{DEVICE 6}

(https://itunes.apple.com/us/app/device-6/idb80366065?mt=8)

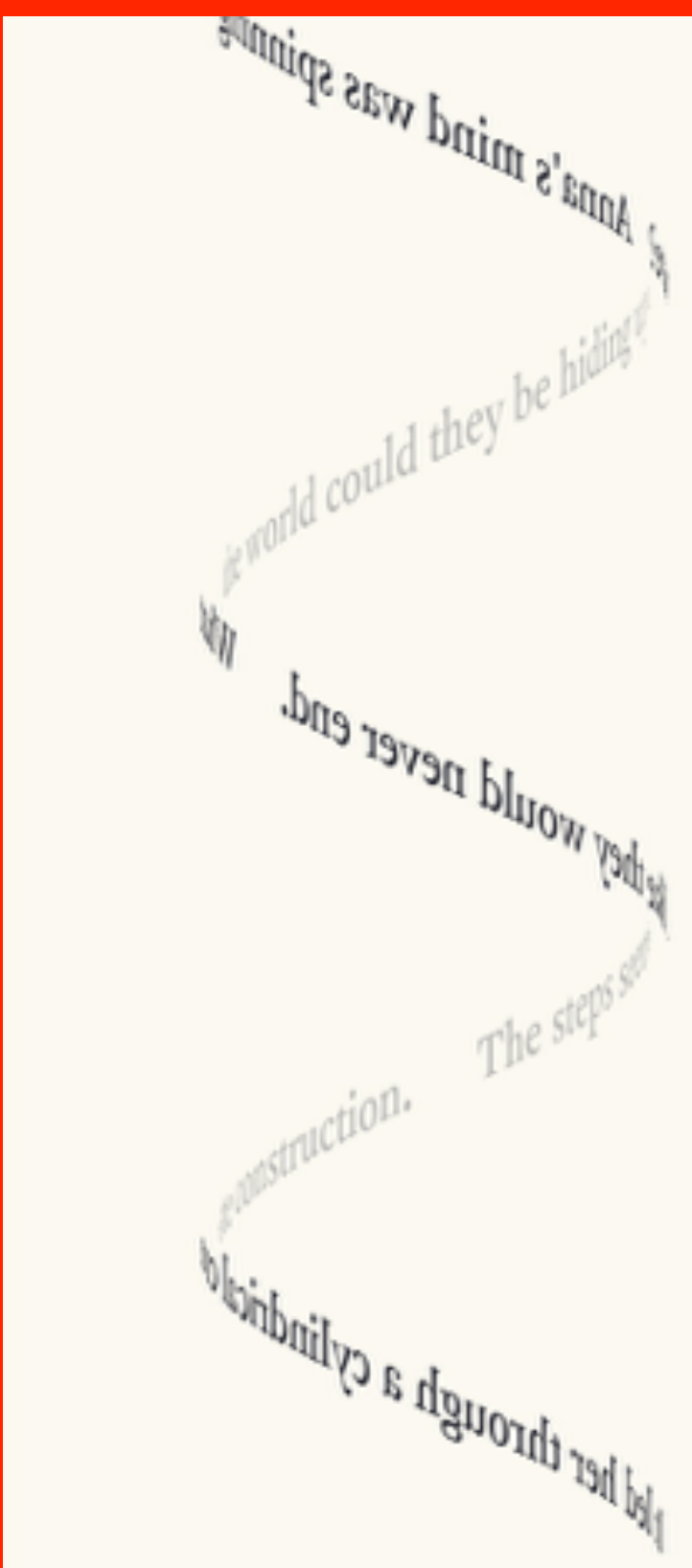




\section{DEVICE 6}

(https://itunes.apple.com/us/app/device-6/id680366065?.mt=8) 


\section{PRINCIPLE \#2:}

The SURPRISE OF ERSATZ TACTILITY 
What happens when you touch

everything? 


\section{YELLOW SUBMARINE}

(https://itunes.apple.com/us/book/yellow-submarine-english/id479687204?.mt=11)

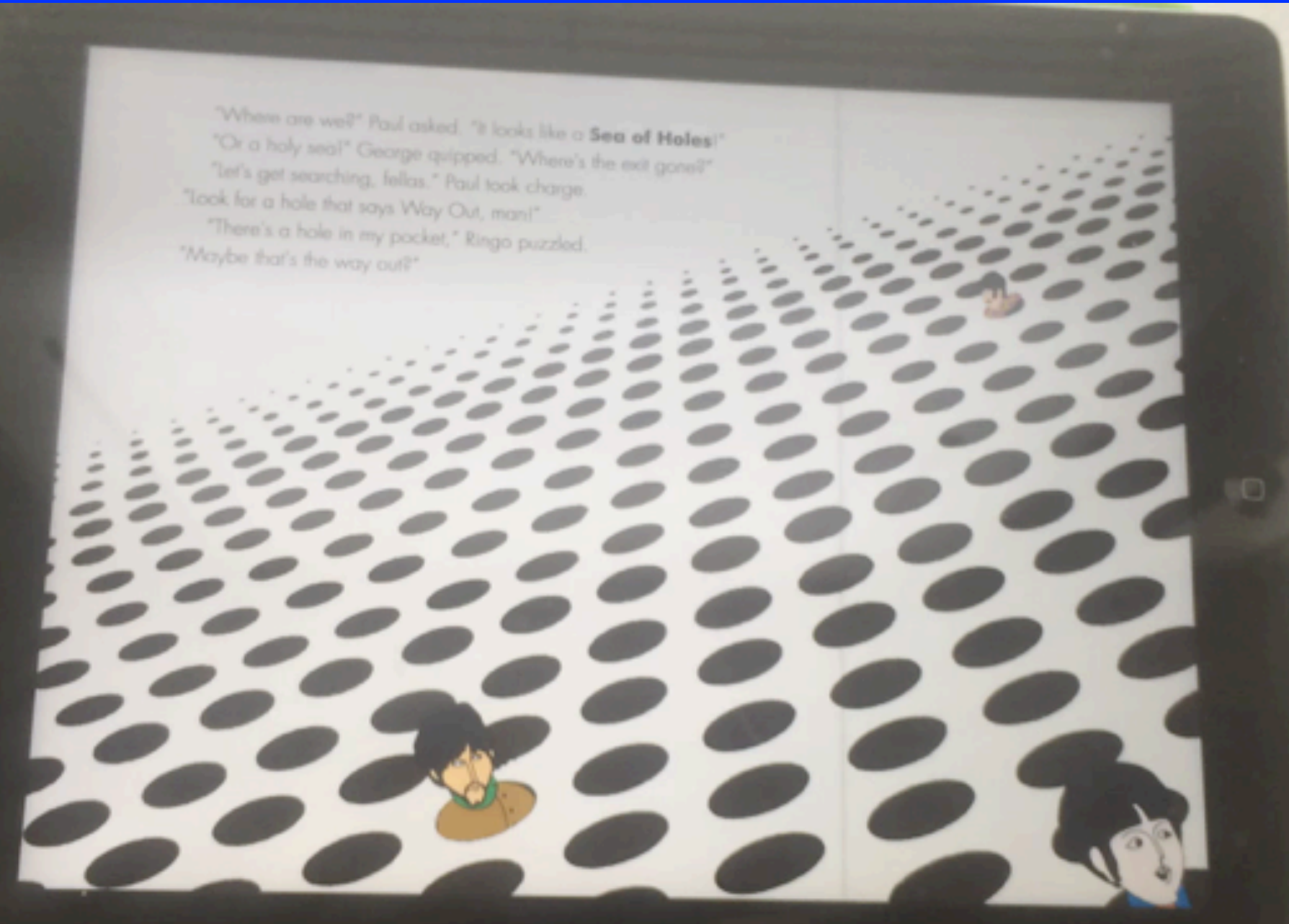




\section{YELLOW SUBMARINE}

(https://itunes.apple.com/us/book/yellow-submarine-english/id479687204?.mt=I1)

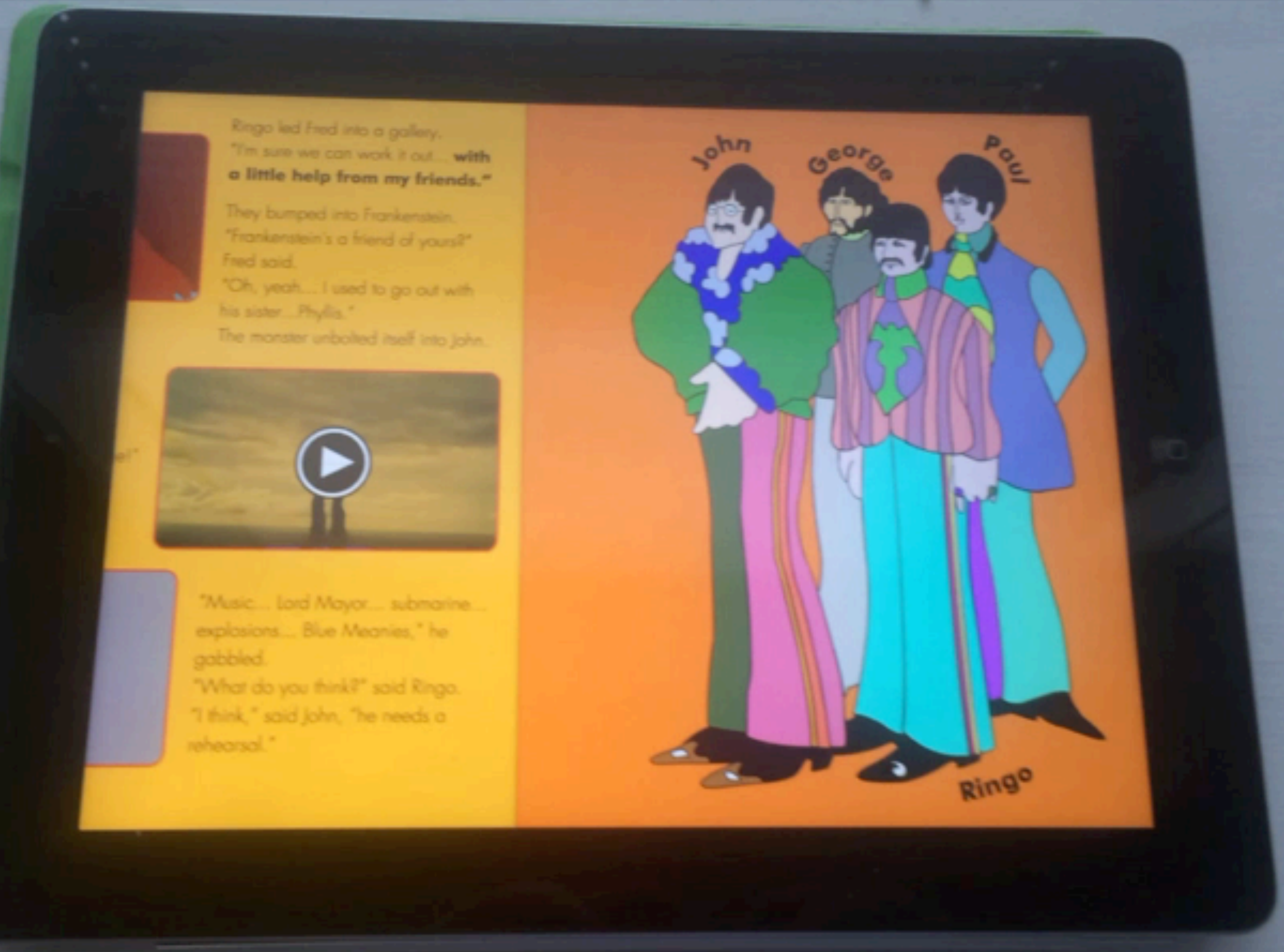




\section{PRINCIPLE \#3:}

NARRATIVE

PliabILITY 


\section{Choose your own ebook adventure}




\section{DAYS}

(https://itunes.apple.com/us/app/80-days/id892812659? mt=8)

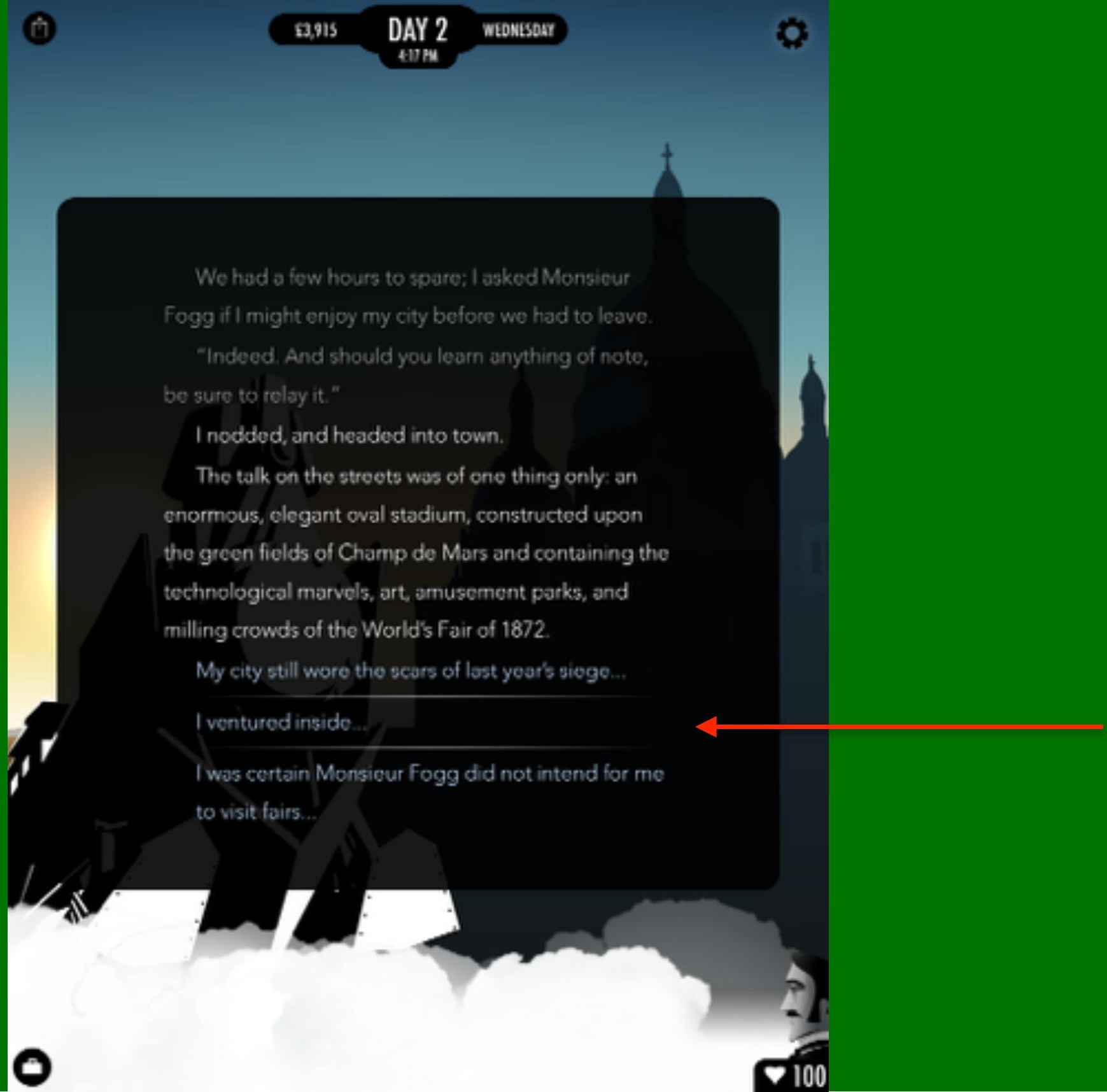




\section{DAYS}

(https://itunes.apple.com/us/app/80-days/id892812659? mt=8)

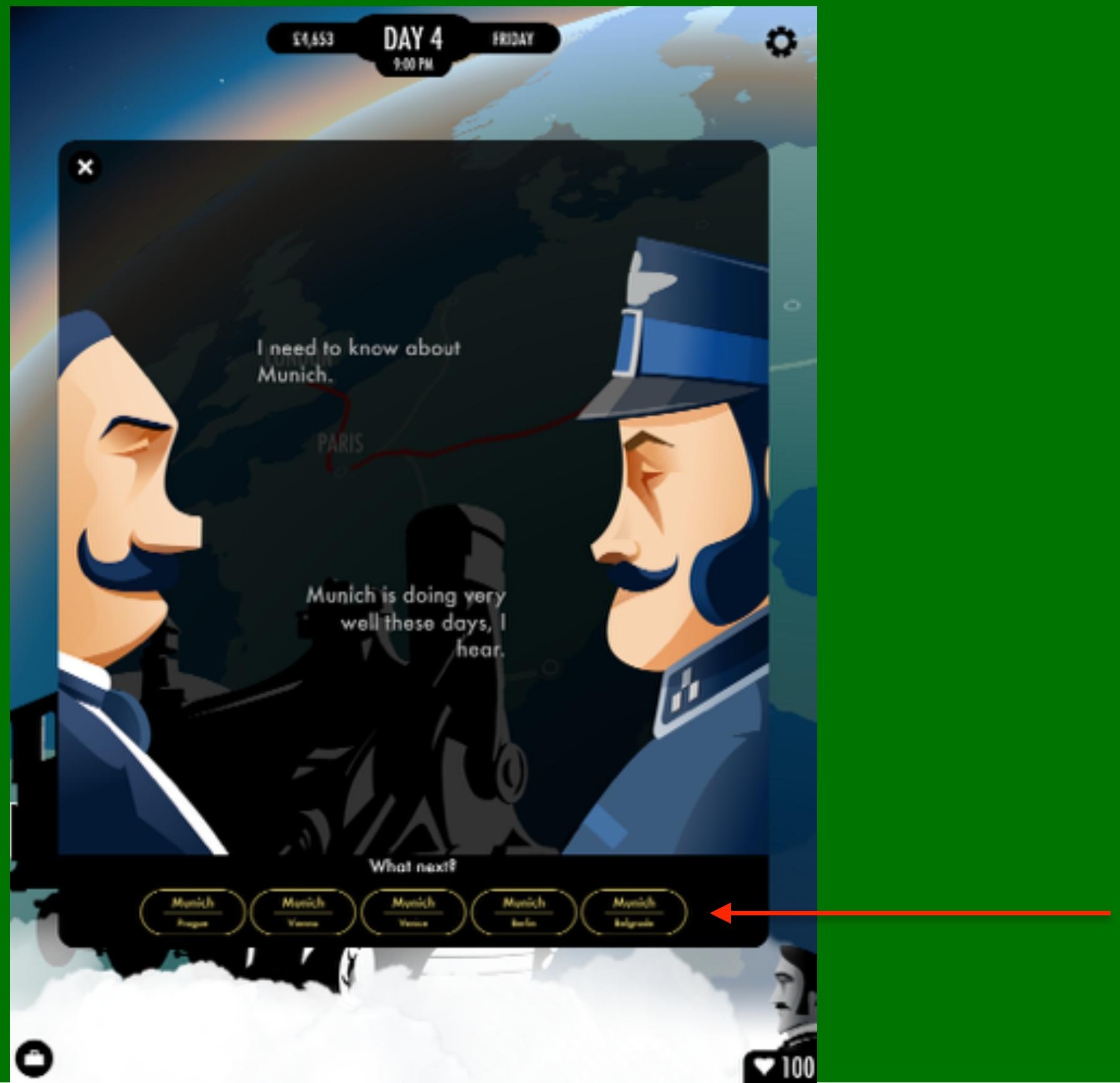




\section{DAYS}

(https://itunes.apple.com/us/app/80-days/id892812659? mt=8)

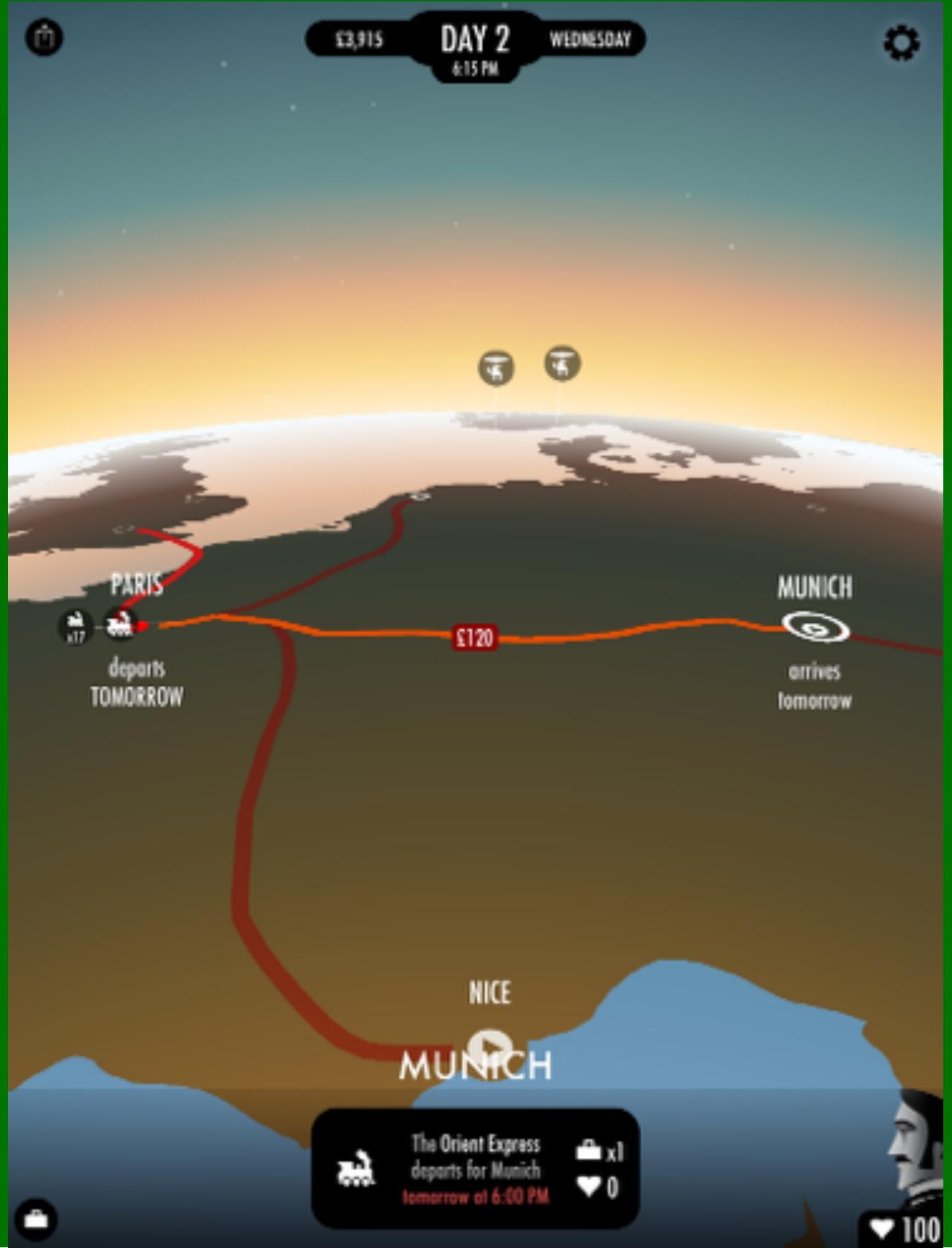


AVANT-GARDE WIDGETS FOR EPUB 3 http://github.com/sandersk/ebook_avant_garde 


\section{INVISIBLD DINK}

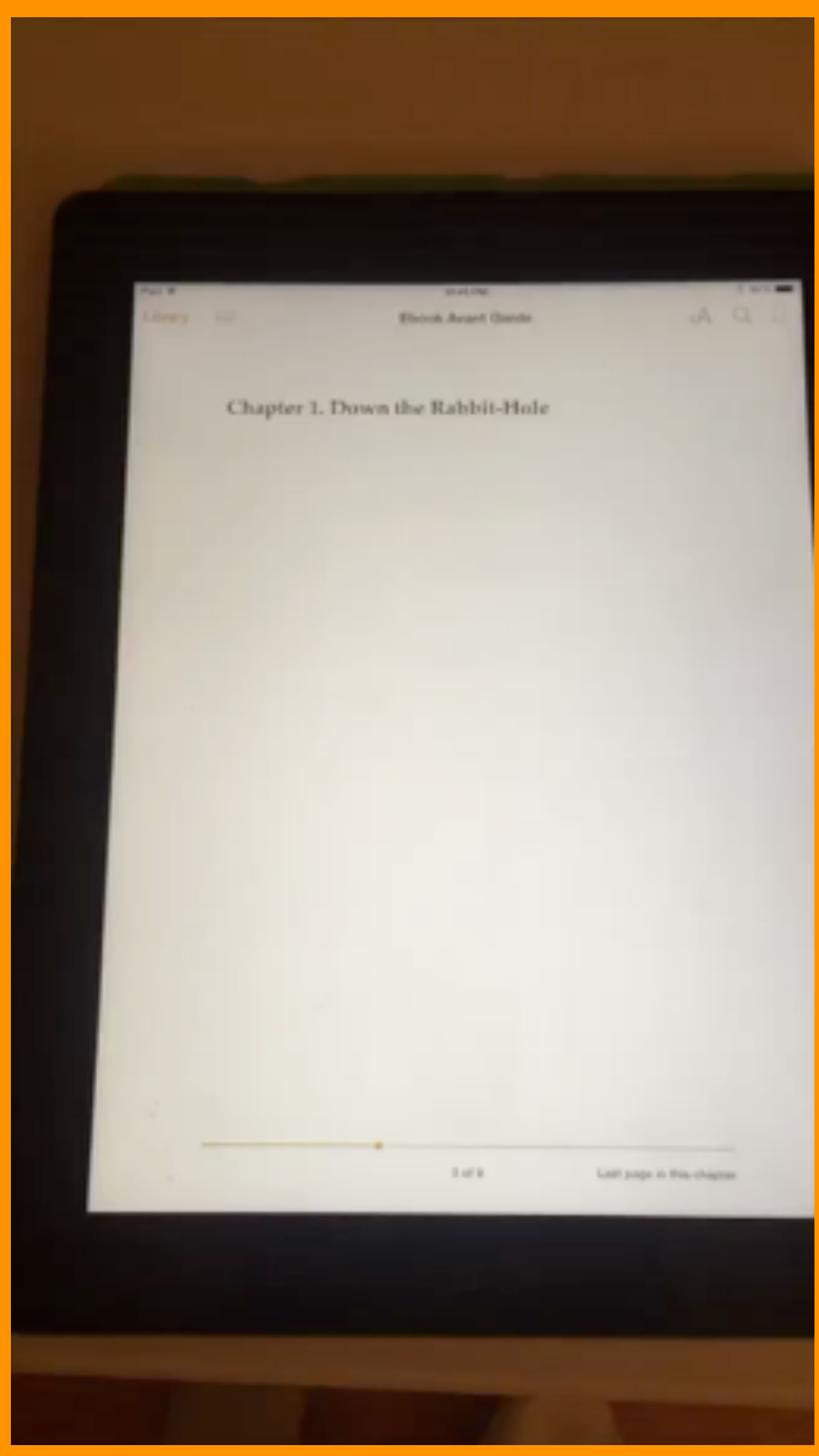

http://github.com/sandersk/ebook_avant_garde 


\section{CSI: DPUB}

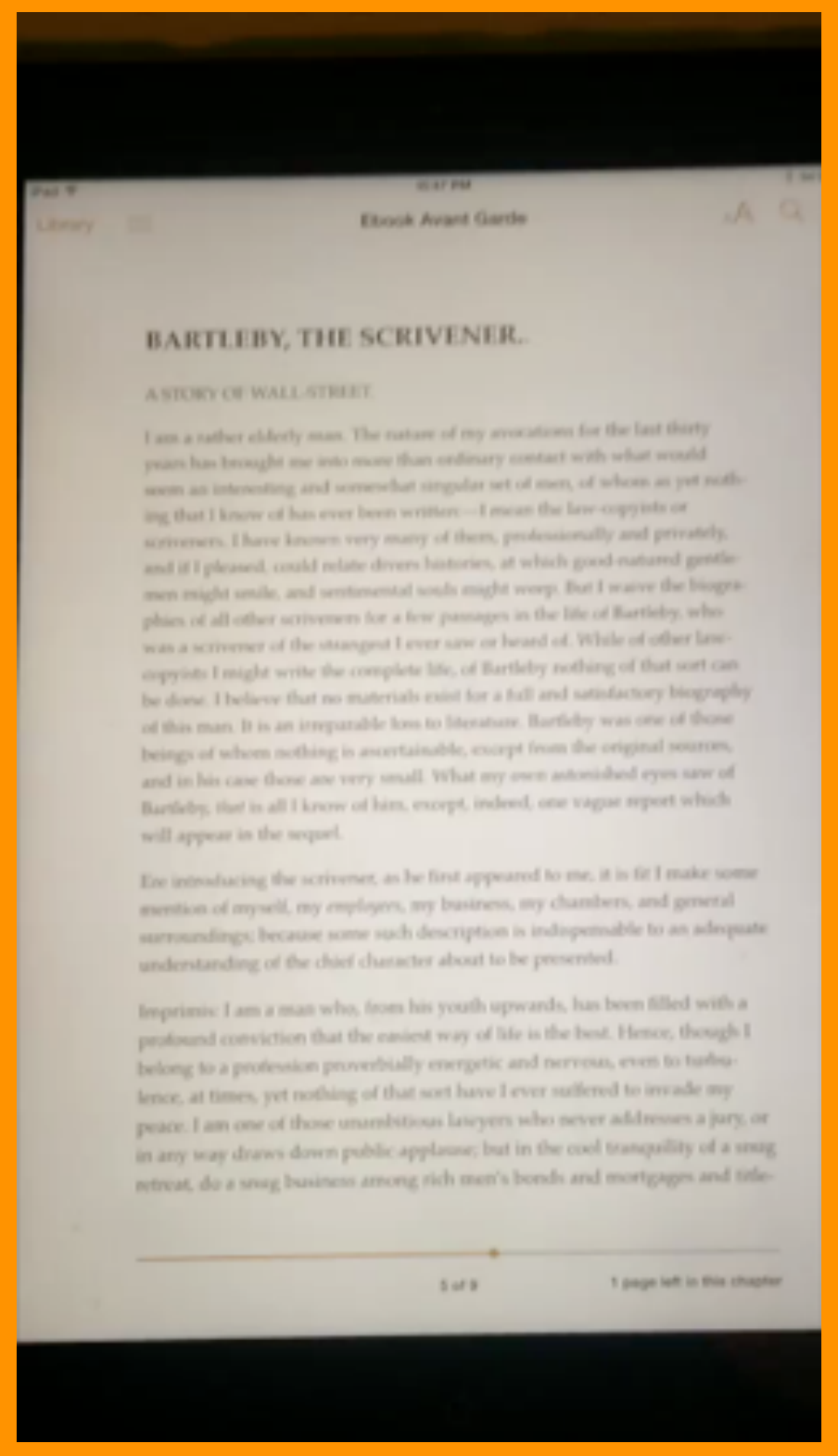

http://github.com/sandersk/ebook_avant_garde 


\section{MATHORANDOM(SHAKDSPEARE)

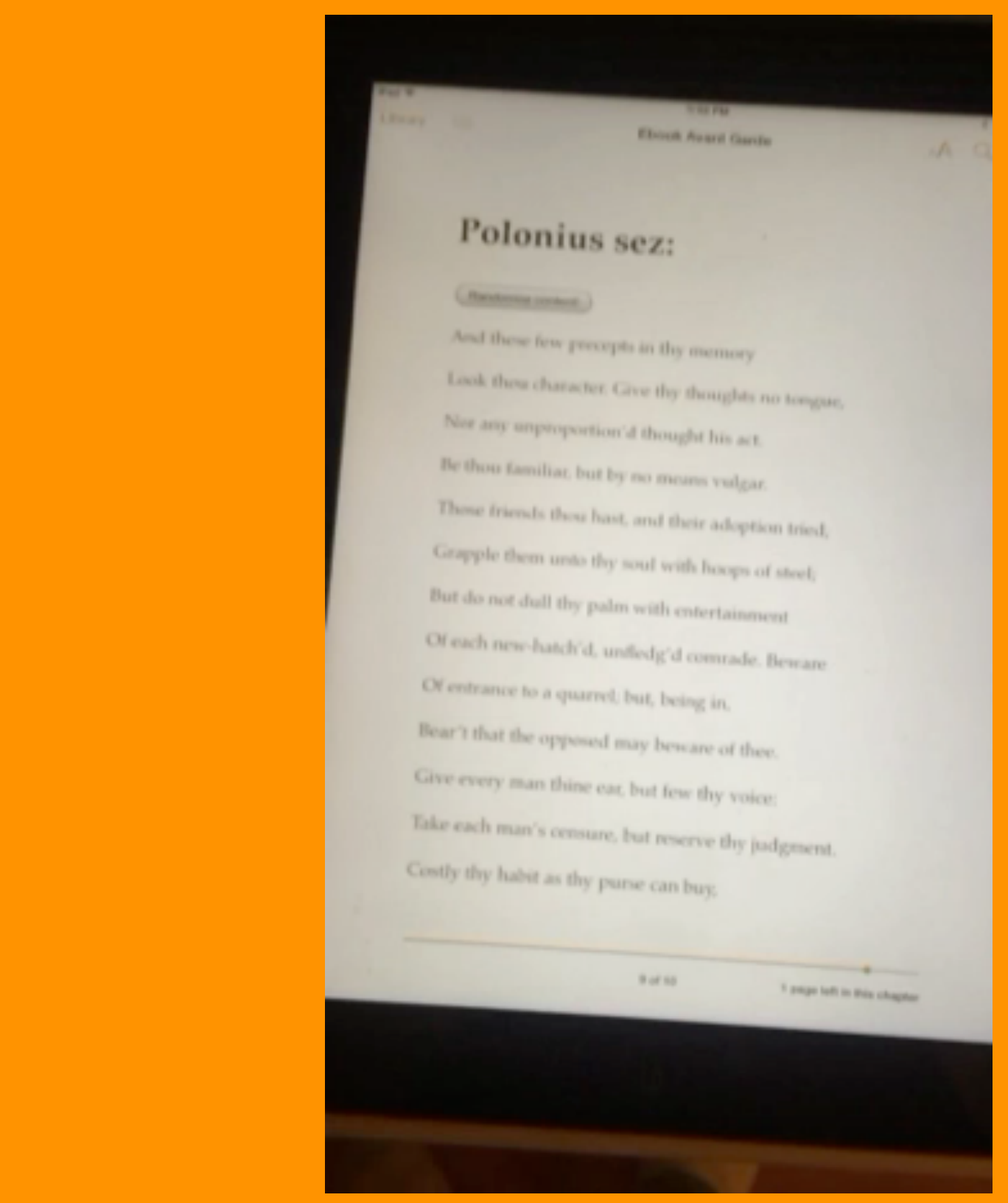

http://github.com/sandersk/ebook_avant_garde

Polonius sez:

Cod the thationer Gave thy theuglas no tunou

Ner any enporportion d though his a

Ae thes foniliar but by no meoms velear

These inmols thow hast, and tevir adyetien tris

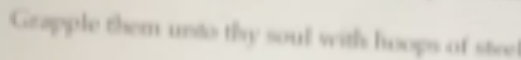

But do nos dull thy palm widh entertainement

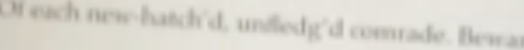

Or entranie bo a vournel but, being in

Bear? thut the opresed may beseane of the

Give nery man thine ear but few thy void

Tale each man's censure, tut noserve dhy padgrow

Cestly thy habit as thy pune can buy

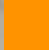

.

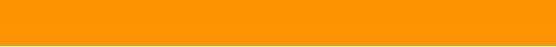




\section{Thank You for Watching!}

\section{Contact Me:}

sanders@oreilly.com (asandersk 